\title{
A population of lymphocytes in human blood distinctive in morphology and other characteristics
}

\author{
H. SMITH AND R. J. COLLINS \\ From the Department of Pathology, Royal Brisbane Hospital, Queensland, Australia
}

SUMMARY Evidence is presented that lymphocytes characterised by being large and having abundant feebly staining, and usually profusely granulated cytoplasm ('pale' cells) are a group which is distinct from the other small basophilic ('dark') cells. In patients with genetic storage disorders characterised by abnormalities of lymphocyte structure, the structural peculiarities were confined to the basophilic cells, and cytochemical differences were found between the 'pale' and 'dark' cells in normal subjects.

It is traditional to recognise, in stained films of human blood, varieties of lymphocyte such as 'small' and 'large' (Bessis, 1973). However, no convincing evidence has been obtained that the morphological distinctions recognised are an indication of differences in biological properties. While, for example, a deficiency of 'small' lymphocytes is described in disorders of 'cellular' immunity (Good, 1973; Hong and Ammann, 1973; Stiehm, 1973), it has also been maintained that ' $T$ ' and ' $B$ ' cells appear identical by light microscopy (Good, 1972; Lawton and Cooper, 1973).

In an investigation of genetic storage disorders characterised by abnormalities of lymphocyte structure, it was found that only lymphocytes with basophilic cytoplasm were affected-these appeared to be the same as 'small' lymphocytes; on the other hand, the abnormalities spared a group of lymphocytes characterised by being large and having abundant cytoplasm, which stained poorly and was usually heavily granulated-these appeared to be the same as 'large' lymphocytes.

This selective involvement suggested that, in addition to morphological differences between these groups, there are functional differences, manifested in these patients by different susceptibility to abnormal storage of metabolites.

This paper details evidence of this selective involvement and gives further evidence of differences between the two groups of lymphocyte obtained by cytochemical examination of normal subjects.

Received for publication 9 August 1976

\section{Patients and their controls}

Thirteen patients with genetic storage disorders characterised by abnormalities of lymphocyte structure were examined (Table 1). There were two sets of sibships (cases 8 and 9, and cases 11, 12, and 13). Patient 1 was examined on two different occasions.

Each case was matched for both age and sex with normal controls-for children over 1 year, matched for age in years at last birthday; for the 7-week infant (case 1a), the controls varied in age from 3 to 14 weeks; and the two controls for the 8-month infant (case 5) were aged 7 months. A total of 81 controls was examined. All were healthy subjects, with no history of recent infection, whose blood counts and blood films were normal, and whose serum immunoglobulins $\mathbf{G}, \mathbf{A}$, and $\mathbf{M}$, determined by radial immunodiffusion, were within normal limits for age. The upper limit of normal for count of eosinophils in blood was taken as $<0.7 \times 10^{9} / 1$ in children under 5 years of age and $<0.5 \times 10^{9} / 1$ in those over the age of 5 years.

\section{Methods}

For examination of lymphocyte morphology and cytochemistry, and for measurement of cell size, air-dried films of un-anticoagulated blood obtained by finger prick or venepuncture were used. For Romanowsky staining, the Jenner-Giemsa or, in one case (No. 5), the May-Grünwald-Giemsa procedure (Dacie and Lewis, 1968) was used; for 
Table 1 Data on patients with genetic abnormality of lymphocyte structure

\begin{tabular}{|c|c|c|c|c|c|c|}
\hline \multirow[t]{3}{*}{ Case } & \multirow[t]{3}{*}{$\operatorname{Sex}$} & \multirow[t]{3}{*}{ Age } & \multicolumn{3}{|c|}{ Blood lymphocytes: $\%$ with abnormal } & \multirow[t]{3}{*}{ Diagnosis } \\
\hline & & & \multirow[t]{2}{*}{ Vacuolation } & \multicolumn{2}{|l|}{ Granulation } & \\
\hline & & & & $\begin{array}{l}\text { Abnormal in } \\
\text { Romanowsky }\end{array}$ & Metachromatic & \\
\hline $\begin{array}{l}a \mathrm{a} \\
1 \mathrm{~b}\end{array}$ & $\mathbf{F}$ & $\begin{array}{l}7 \mathrm{wk} \\
2 \mathrm{yr}\end{array}$ & $\begin{array}{l}47 \\
47\end{array}$ & & & GM1 gangliosidosis, juvenile type \\
\hline 2 & $\mathbf{M}$ & $6 y \mathrm{yr}$ & 36 & & & Neuronal lipofuscinosis \\
\hline 3 & $\mathbf{M}$ & $7 \mathrm{yr}$ & 60 & & & Undiagnosed storage disease \\
\hline 4 & $\mathbf{M}$ & $14 \mathrm{yr}$ & 58 & & & Neuronal lipofuscinosis \\
\hline 5 & $\mathbf{F}$ & $8 \mathrm{mth}$ & & 32 & 26 & Hurler mucopolysaccharidosis \\
\hline 6 & $\mathbf{M}$ & $5 \mathrm{yr}$ & & 44 & 29 & Hurler mucopolysaccharidosis \\
\hline 7 & $\mathbf{M}$ & $12 \mathrm{mth}$ & & 55 & 61 & Hunter mucopolysaccharidosis \\
\hline 8 & $\mathbf{M}$ & $9 \mathrm{yr}$ & & 40 & 21 & Hunter mucopolysaccharidosis \\
\hline 9 & $\mathbf{M}$ & $11 \mathrm{yr}$ & & 46 & 36 & Hunter mucopolysaccharidosis \\
\hline 10 & $\mathbf{F}$ & $3 \mathrm{yr}$ & & 30 & 28 & Maroteaux-Lamy mucopolysaccharidosis \\
\hline 11 & $\mathbf{M}$ & $6 \mathrm{yr}$ & & 43 & 38 & San Filippo mucopolysaccharidosis \\
\hline 12 & $\mathbf{F}$ & $9 \mathrm{yr}$ & & 38 & 51 & San Filippo mucopolysaccharidosis \\
\hline 13 & $\mathbf{M}$ & $13 \mathrm{yr}$ & & 41 & 40 & San Filippo mucopolysaccharidosis \\
\hline
\end{tabular}

toluidine blue, the method of Muir et al. (1963); for peroxidase, the method of Kaplow (1965) with Giemsa $1 / 10$ as counterstain; for periodic acidSchiff (PAS), the method of Dacie and Lewis (1968); for non-specific esterase and chloro-acetate esterase, the methods of Yam et al. (1971) with the exception that Mayer's haemalum was used as counterstain instead of methyl green; for $\beta$-glucuronidase, the method of Lorbacher et al. (1967); and for acid phosphatase, the method of Goldberg and Barka (1962).

Films were examined in the narrow zone behind the tails where the smear was no more than one or two cells thick, the other areas being unsuitable because of artefacts of staining and structure. Cytological examinations were made with a Zeiss $\times 100$ N.A. 1.3 'neofluar' oil-immersion objective with oil on the substage condenser. In the enumeration of granules, only cytoplasmic granules were counted. The error in duplicate counts was $\pm 5 \%$. Usually at least 100 lymphocytes were examined for cytological characteristics in individual films. Cells were measured with a micrometer eyepiece and size expressed as the mean of the longest axis of the cell, and of the axis at right-angles to this.

Total leucocyte counts were made with a Coulter $S$ electronic counter. Differential counts were made on a minimum of $\mathbf{3 0 0}$ leucocytes. Plasma cells and atypical mononuclear cells were not counted as lymphocytes.

For evaluation of phagocytosis in vitro, 3 to $4 \mathrm{ml}$ of venous blood were taken into lithium heparin and exposed to latex particles $(0.81 \mu \mathrm{m}$, Difco Labs, Detroit, Michigan), or Staphylococcus aureus (recent isolate of pathogen from patient, suspension in trypticase soya bean broth), by gentle rotation at $30 \mathrm{rpm}$ for $\frac{1}{2} \mathrm{~h}$ at $37^{\circ} \mathrm{C}$. Films were made by spreading on standard slides and stained by standard Roman- $\overline{3}$ owsky procedures and, in some cases, by Gram stain as well. There was rarely difficulty in deciding if ${ }^{\supset}$ particles had or had not been phagocytosed. In the $\vec{\varphi}$ Staph. aureus preparations, because of the possibility.. of organisms being confused with nuclear debris, cells were regarded as containing organisms only when at least a proportion of the inclusions were $\bar{\partial}$ grouped in pairs or larger aggregates.

In statistical analyses, differences were regarded $\stackrel{\circ}{\Phi}$ as significant if $P$ was $\mathbf{0 . 0 5}$ or less.

MORPHOLOGICAL CHARACTERISTICS OF DARK LYMPHOCYTES, PALE LYMPHOCYTES, ANDO MONOCYTES

\section{In films stained by Romanowsky procedures}

The characteristics which distinguished pale and $\frac{0}{3}$ dark lymphocytes from each other and from monocytes are listed in Table 2 and illustrated in Figs. 10 and $3 \mathrm{~b}$. The most useful identifying features of dark lymphocytes were their small size and scanty, 을 basophilic, usually sparsely granulated cytoplasm; $>$ pale lymphocytes were larger with abundant, profusely granulated, feebly basophilic cytoplasm. $N$ Monocytes were larger still with large, irregular nuclei and abundant, granulated cytoplasm of 0 'ground-glass' texture. Lymphocytes which could No not be classified as 'pale' or 'dark' were recorded as? unclassified. Plasma cells and atypical mononucleare cells were not recorded as lymphocytes.

The alterations of granulation or vacuolation in $\stackrel{+}{+}$ genetic disorders of lymphocyte structure did not 7 affect identifying features.

In films treated with other stains In the peroxidase preparations, the Giemsa counter- $\bar{O}$ stain enabled ready differentiation of cell types. 
Table 2 Characteristics of 'dark' lymphocytes, 'pale' lymphocytes, and monocytes in Romanowsky stained films of un-anticoagulated blood from normal subjects

\begin{tabular}{llll}
\hline & Dark lymphocytes & Pale lymphocytes \\
\hline $\begin{array}{l}\text { size } \\
\text { outline: fine finger- } \\
\text { like processes } \\
\text { nucleus }\end{array}$ & $\begin{array}{l}\text { small to medium }(10-14 \mu \mathrm{m}) \\
\text { occasional }\end{array}$ & $\begin{array}{l}\text { medium to large (13-17 } \mu \mathrm{m}) \\
\text { rare if at all } \\
\text { central or eccentric; multiple } \\
\text { indentation uncommon }\end{array}$ & $\begin{array}{l}\text { lasually eccentric; less intense stain } \\
\text { than in dark cells; multiple } \\
\text { indentation common }\end{array}$ \\
$\begin{array}{l}\text { cytoplasm } \\
\text { amount } \\
\text { stain }\end{array}$ & $\begin{array}{l}\text { usually scanty } \\
\text { deeply basophil; rectangular or } \\
\text { rhomboidal crystal-like defects } \\
\text { in rare cells } \\
\text { common, usually sparse and fine }\end{array}$ & $\begin{array}{l}\text { usually abundant } \\
\text { pale blue-grey, insubstantial or } \\
\text { empty-looking }\end{array}$ \\
$\begin{array}{l}\text { granulation } \\
\text { vacuolation }\end{array}$ & $\begin{array}{l}\text { invariable or probably so; usually } \\
\text { profuse and coarser than in dark cells } \\
\text { common; usually not numerous or } \\
\text { large; may be poorly defined }\end{array}$ \\
\hline
\end{tabular}

'The figures were obtained in one normal adult.

With the other cytochemical procedures, though the counterstain might not reveal azurophil granulation or do so only feebly, other characteristics enabled distinction of cell types. Differentiation in the non-specific esterase preparations, for example, is illustrated in Fig. 4; and, as an example of identifiability of cell types in toluidine blue treated films, the percentage of lymphocytes identified as pale in paired films, stained respectively by Romanowsky and toluidine blue, from the nine patients with mucopolysaccharidosis were: 8 and 11,14 and 13,6 and 6,18 and 19,8 and 10,9 and 18,13 and 12 , 3 and 2 , and 16 and 12 .

CRITERIA OF ABNORMALITY OF LYMPHOCYTES IN PATIENTS WITH GENETIC STORAGE DISEASE In disorders in which abnormal vacuolation of lymphocytes was a feature (Table 1, cases 1 to 4), lymphocytes were classified as abnormally vacuolated only when vacuoles were large, profuse, and aggregated in groups (Fig. 2). There was rarely difficulty in distinguishing abnormal vacuoles from the one to a few small vacuoles in most normal lymphocytes (Fig. 1). The occasional cell whose vacuolation caused doubt was classified separately.

In the mucopolysaccharidoses (Table 1, patients 5 to 13), lymphocytes were regarded as abnormal in Romanowsky stained films only when granules were coarse, intensely stained (there might be 'seepage' around them), and arranged in groups (Fig. 3). Most of the granules in abnormal cells were round or angular but some had the shape of circles, crescents, rods or other unusual configurations. In these cells, granules often lay individually in clear vacuoles. Cells in which granulation could not be confidently classified as normal or abnormal were recorded separately. In films stained with toluidine blue, granules were regarded as abnormal only when they stained a definite pink, red, orange or violet. Abnormal granulation could be readily distinguished from the sparse, scattered, barely pink granules which may occur in a proportion of pale lymphocytes in normal subjects. There was usually good agreement between the percentage of lymphocytes judged to be abnormal in paired films stained by Romanowsky and toluidine blue (Table 1).

\section{Results}

\section{QUANTITATIVE HAEMATOLOGY}

Frequency of structural abnormality in dark compared with pale lymphocytes in patients with genetic disorders of lymphocyte structure

The proportions of dark and pale lymphocytes affected by structural abnormality in these patients are compared in Table 3. In the patients with abnormal vacuolation, results were obtained for Romanowsky stained films only; in the patients with mucopolysaccharidosis, results were obtained for paired films stained by Romanowsky and by toluidine blue methods. Pale lymphocytes were either not affected, or only rare cells were questionably abnormal in two patients (6 and 11). The differences between pale and dark lymphocytes were significant in all cases except no. 12, in whom the number of pale cells found was too small to be of statistical significance.

\section{Absolute counts and granulation of pale lymphocytes in patients and controls}

These data are given in Table 4. The count of pale cells fell within the range for controls except for a slight decrease in case 12, and an increase in cases 1a and 6. Cell granulation fell within the range for controls, except for some increase in cases 1a and 10 , and decrease in cases 6,9 , and 13. 

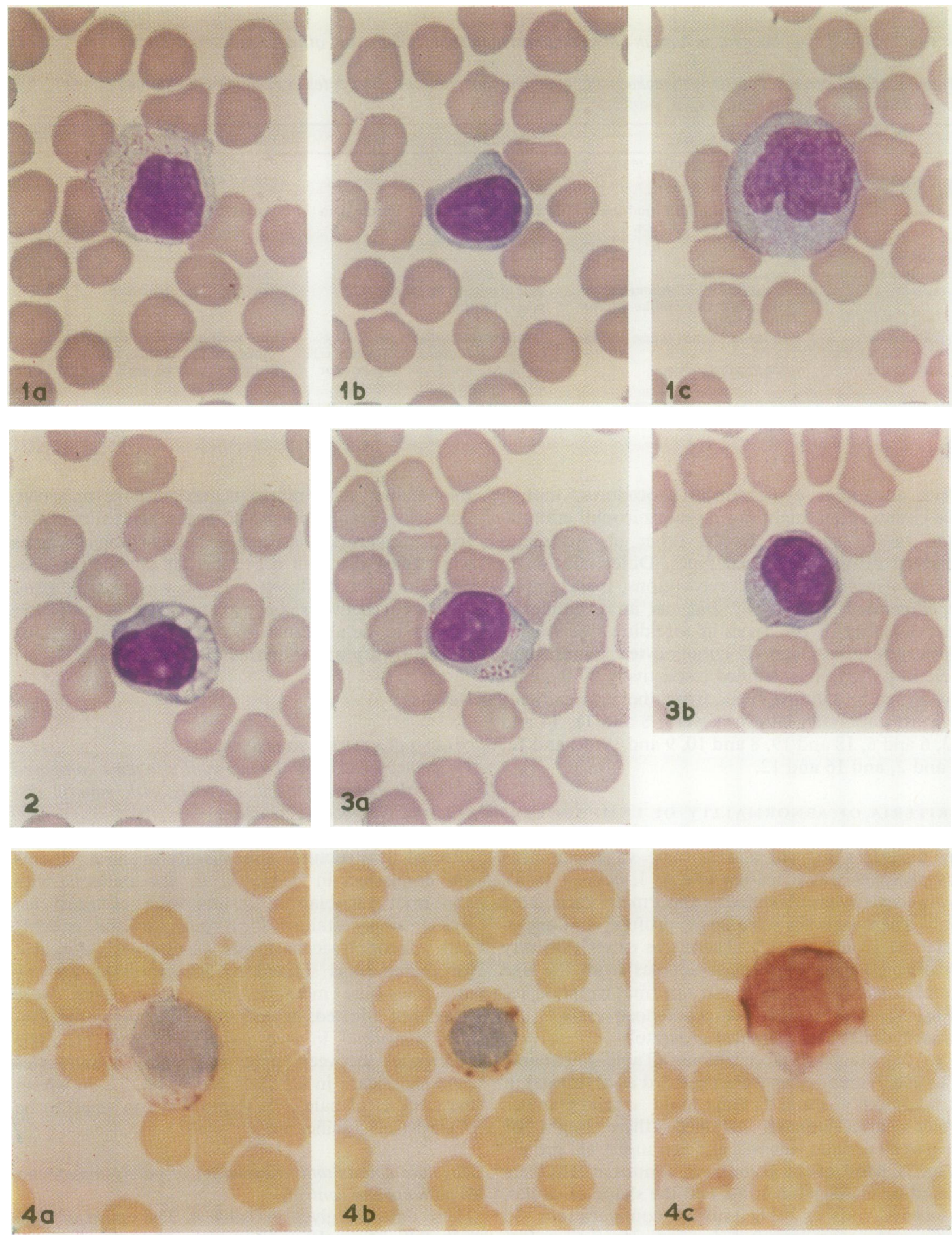

Fig. 1 (a) Pale lymphocyte, (b) dark lymphocyte, and (c) monocyte. The pale lymphocyte contains numerous granules. The dark lymphocyte contains a vacuole at one pole but no granules. Blood film, normal subject. Jenner-Giemsa $\times 1300$.

Fig. 2 Abnormal vacuolated lymphocyte in blood film from a patient with uncharacterised storage disease (Table 1, case 3). Jenner-Giemsa $\times 1300$.

Fig. 3 (a) Abnormally granulated lymphocyte and (b) a normal, granulated, dark lymphocyte in blood film from a patient with Hunter mucopolysaccharidosis (Table 1, case 8). Jenner-Giemsa $\times 1300$.

Fig. 4 Non-specific esterase cytochemistry of (a) pale lymphocyte, (b) dark lymphocyte, and (c) monocyte. The lymphocytes contain granular areas of reaction, and, in the dark lymphocyte, coarse dense deposits as well; in the monocyte, reaction is diffuse. Blood film, normal subject $(\times 1300)$. 
Table 3 Proportion of dark lymphocytes and of pale lymphocytes affected by abnormality in patients with genetic disorders of lymphocyte structure

\begin{tabular}{|c|c|c|c|c|c|c|c|c|c|}
\hline \multirow[t]{3}{*}{ Case $^{1}$} & \multirow[t]{3}{*}{ Abnormality } & \multicolumn{8}{|c|}{ Proportion of abnormal ${ }^{2}$ lymphocytes revealed by } \\
\hline & & \multicolumn{4}{|c|}{ Romanowsky stain } & \multicolumn{4}{|c|}{ Toluidine blue } \\
\hline & & Dark & Pale & $x^{2}$ & $\mathbf{P}^{3}$ & Dark & Pale & $x^{2}$ & $\mathbf{P}^{3}$ \\
\hline$\overline{1 a}$ & vacuolation & $47 / 70$ & $0 / 30$ & 38.01 & $<0.001$ & & & & \\
\hline $1 \mathrm{~b}$ & ", & $46 / 91$ & $0 / 8$ & $8 \cdot 19$ & $<0.01$ & & & & \\
\hline 2 & ", & $36 / 74$ & $0 / 22$ & $17 \cdot 12$ & $<0.001$ & & & & \\
\hline 3 & ", & $50 / 86$ & $0 / 12$ & $14 \cdot 24$ & $<0.001$ & & & & \\
\hline 4 & & $58 / 86$ & $0 / 13$ & $21 \cdot 17$ & $<0.001$ & & & & \\
\hline 5 & granulation & $33 / 92$ & $0 / 8$ & & 0.05 & $27 / 91$ & $0 / 11$ & & 0.03 \\
\hline 6 & , & $43 / 83$ & $? 1 / 14$ & $9 \cdot 64$ & $<0.01$ & $46 / 137$ & $? 1 / 21$ & $7 \cdot 23$ & $<0.01$ \\
\hline 7 & , & $53 / 94$ & $0 / 6$ & & 0.01 & $61 / 94$ & $0 / 6$ & & 0.003 \\
\hline 8 & , & $39 / 77$ & $0 / 18$ & 15.47 & $<0.001$ & $34 / 124$ & $0 / 31$ & $10 \cdot 89$ & $<0.001$ \\
\hline 9 & ", & $46 / 87$ & $0 / 8$ & & 0.01 & $48 / 118$ & $0 / 14$ & $8 / 95$ & $<0.01$ \\
\hline 10 & ," & $30 / 89$ & $0 / 9$ & & 0.05 & $28 / 81$ & $0 / 18$ & 8.68 & $<0.01$ \\
\hline 11 & ", & $43 / 84$ & $? 1 / 13$ & $9 \cdot 41$ & $<0.01$ & $38 / 85$ & $? 1 / 12$ & & 0.02 \\
\hline 12 & " & $38 / 94$ & $0 / 3$ & & 0.28 & $51 / 96$ & $0 / 2$ & & $0 \cdot 23$ \\
\hline 13 & " & $41 / 82$ & $0 / 16$ & 13.75 & $<0.001$ & $47 / 113$ & $0 / 14$ & $9 \cdot 24$ & $<0.01$ \\
\hline
\end{tabular}

${ }^{1}$ In the patients with mucopolysaccharidoses ( 5 to 13 ), films for Romanowsky and toluidine blue had been taken simultaneously.

${ }^{2}$ Doubtful lymphocytes (? dark, ? pale) have not been included because of their small number (no more than $5 \%$ in any patient) and the fact that their inclusion did not materially affect the statistical evaluations.

${ }^{3}$ Fisher's exact test used instead of $\chi^{2}$ when expected values were small.

\section{Absolute counts of total and dark lymphocytes in patients and controls}

These data are given in Table 5. In all cases except no. 10, though abnormal lymphocytes were present in substantial numbers, figures for total lymphocytes and for dark lymphocytes did not exceed the range for the controls. In case 10 , values for total and for dark lymphocytes exceeded the upper limit in the controls by a difference approximating the count of abnormal cells.

CYTOCHEMISTRY OF DARK LYMPHOCYTES, PALE LYMPHOCYTES, AND MONOCYTES

These data are summarised in Table 6. Dark and pale lymphocytes differed notably in the frequency or type of reaction for non-specific esterase (see also Fig. 4), $\beta$-glucuronidase, and acid phosphatase.
PHAGOCYTIC CAPACITY OF DARK LYMPHOCYTES, PALE LYMPHOCYTES, AND MONOCYTES Phagocytosis was assessed in vitro in blood from six adults who were clinically normal or who had nonhaematological disorders. Except for questionable phagocytosis by rare lymphocytes, neither pale nor dark types were phagocytic. The proportion of monocytes which had ingested latex varied from 86 to $100 \%$, and Staph. aureus from 54 to $100 \%$.

\section{Discussion}

The present investigation suggests that in the genetic disorders examined, the characteristic abnormalities of lymphocyte structure were confined to cells with basophilic cytoplasm, and did not affect a group of cells characterised by being larger and having more

Table 4 Counts and granulation of pale lymphocytes in patients with genetic disorders of lymphocyte structure and in normal controls

\begin{tabular}{|c|c|c|c|c|c|c|c|}
\hline \multirow[t]{3}{*}{ Case } & \multicolumn{2}{|l|}{ Patients } & \multicolumn{5}{|l|}{ Controls } \\
\hline & \multirow[t]{2}{*}{ Count $\times 10^{2} / l$} & \multirow{2}{*}{$\begin{array}{l}\text { Granules per cell: } \\
\text { Average }\end{array}$} & \multirow[t]{2}{*}{ Number } & \multicolumn{2}{|c|}{ Count $\times 10^{\circ} / l$} & \multicolumn{2}{|c|}{ Average granules per cell } \\
\hline & & & & Mean & Range & Mean & Range \\
\hline$\overline{1 \mathrm{a}}$ & 1.86 & 62 & 6 & $0 \cdot 31$ & $0.00-0.56$ & 37 & $27-57$ \\
\hline $1 b$ & 0.30 & 56 & 2 & 0.43 & $0.16-0.70$ & 61 & $42-80$ \\
\hline 2 & 0.79 & 62 & 9 & 0.35 & $0.15-0.83$ & 50 & $38-64$ \\
\hline 3 & $0 \cdot 38$ & 58 & 5 & 0.29 & $0 \cdot 18-0.44$ & 49 & $38-58$ \\
\hline 4 & $0 \cdot 31$ & 41 & 5 & 0.71 & $0 \cdot 30-1 \cdot 17$ & 43 & $33-55$ \\
\hline 5 & $0 \cdot 24$ & 38 & 2 & 0.25 & $0 \cdot 17-0.33$ & 40 & $29-52$ \\
\hline 6 & 0.69 & 32 & 5 & 0.35 & $0.23-0.46$ & 48 & $42-53$ \\
\hline 7 & $0 \cdot 17$ & 66 & 8 & 0.33 & $0.09-0.59$ & 50 & $17-77$ \\
\hline 8 & 0.71 & 52 & 6 & 0.41 & $0.16-0.71$ & 52 & 47-61 \\
\hline 9 & 0.18 & 39 & 7 & $0 \cdot 37$ & $0.16-0.62$ & 51 & 44-63 \\
\hline 10 & 0.44 & 59 & 3 & $0 \cdot 26$ & $0.13-0.45$ & 40 & $33-47$ \\
\hline 11 & 0.49 & 42 & 9 & 0.35 & $0.15-0.83$ & 50 & $38-64$ \\
\hline 12 & 0.06 & 54 & 8 & $0 \cdot 25$ & $0.07-0.44$ & 56 & $42-69$ \\
\hline 13 & 0.48 & 20 & 6 & 0.58 & $0.33-1.04$ & 38 & $35-44$ \\
\hline
\end{tabular}




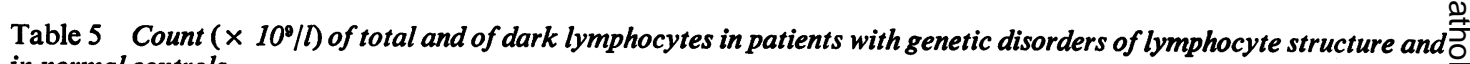
in normal controls

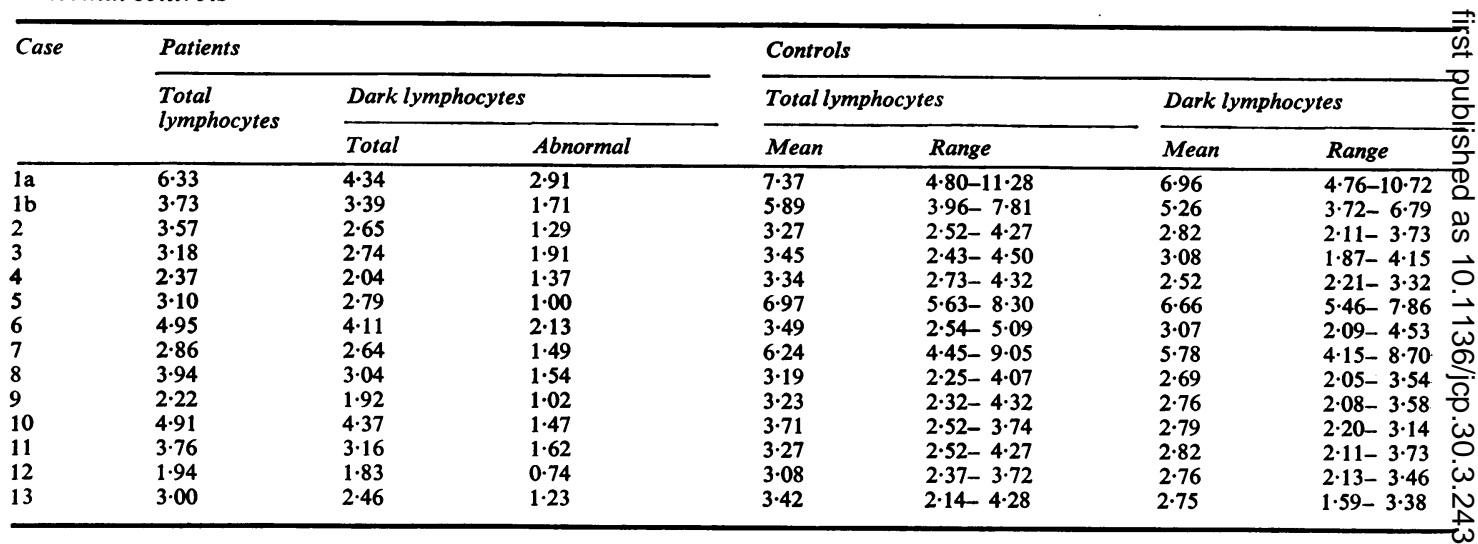

abundant cytoplasm of feeble staining which was usually profusely granulated. This selective involvement suggests that in these patients the groups were distinct in characteristics in addition to morphology.

The pale cells in the patients appeared to be a normal population; their morphology appeared normal, and their counts and granulation were, in most of the cases, within the range for the controls (the influence of infection, to which these patients are susceptible, on the figures is unknown). Likewise the abnormal cells also appeared to be normal 'dark' lymphocytes - with the characteristic structural peculiarities superimposed-and not an additional, new population of cells. This impression was supported by the fact that the counts of dark cells did not, except for one case, exceed the limits for the controls in spite of the substantial numbers affected by the structural peculiarities.

The inference that pale and dark lymphocyte may be distinct groups, not only in the patients but also in normal subjects, was supported by cytoco chemical examination of normals. Notable were differences in frequency or type of reactivity for non-specific esterase, $\beta$-glucuronidase, and acio phosphatase.

It is unlikely that pale cells are monocytes; theie morphology in Romanowsky stained films is nog that of monocytes, their cytochemical reactions examined, especially for peroxidase and chloro은 acetate esterase, differed from those of monocytes? and they were not phagocytic in the systems examined.

Table 6 Cytochemistry of dark lymphocytes, pale lymphocytes, and monocytes in adult normals and patients with non-haematological disorders ${ }^{1}$

\begin{tabular}{|c|c|c|c|}
\hline & Dark lymphocytes & Pale lymphocytes & Monocytes \\
\hline Non-specific esterase $(8)^{2}$ & $\begin{array}{l}72-90 \% \text {; sparse granules and coarse } \\
\text { chunks, usually intense }\end{array}$ & $\begin{array}{l}\text { 0-34\%; azurophil-sized granules, } \\
\text { not intense }\end{array}$ & $\begin{array}{l}73-100 \% \text {; diffuse or finely } \\
\text { granular, often with coarse } \\
\text { aggregates }\end{array}$ \\
\hline Chloro-acetate esterase (4) & questionable in rare cells & $\mathbf{0}$ & $31-80 \% ;$ granular and/or diffuse \\
\hline $\begin{array}{l}\text { Peroxidase (9) } \\
\text { PAS (5) }\end{array}$ & $\begin{array}{l}0 \\
64-92 \% \text {; granules, usually sparse; }\end{array}$ & $\begin{array}{l}0 \\
34-90 \% \text {; moderate to large number }\end{array}$ & $\begin{array}{l}50-100 \% \\
75-100 \% \text {; diffuse, with occasional }\end{array}$ \\
\hline & $\begin{array}{l}\text { also pale, coarse poorly outlined } \\
\text { deposits }\end{array}$ & of granules & granules \\
\hline$\beta$-glucuronidase (5) ${ }^{2}$ & $\begin{array}{l}37-75 \% \text {; sparse, coarse, intense } \\
\text { deposits; diffuse reaction rare }\end{array}$ & $\begin{array}{l}61-100 \% ; \text { moderate to intense } \\
\text { azurophil-sized granules; diffuse } \\
\text { reaction common }\end{array}$ & $\begin{array}{l}85-100 \% \text {; weak diffuse, with } \\
\text { occasional granules }\end{array}$ \\
\hline Acid phosphatase (3) & $\begin{array}{l}70-92 \% \text {; sparse, coarse, usually } \\
\text { intense; diffuse reaction rare }\end{array}$ & $\begin{array}{l}67-75 \% \text {; azurophil-sized granules, } \\
\text { mild to moderate intensity; } \\
\text { diffuse reaction common }\end{array}$ & $\begin{array}{l}65-100 \% \text {; diffuse reaction and } \\
\text { fine to coarse granules, often } \\
\text { intense }\end{array}$ \\
\hline $\begin{array}{l}\text { Toluidine blue } \\
\text { metachromatic } \\
\text { granules }(5)^{8}\end{array}$ & 0 & $0-30 \%$; sparse, mild intensity & 0 \\
\hline \multicolumn{4}{|c|}{$\begin{array}{l}\text { 1Percentages are for positive reaction of any kind; figures in left-hand column are numbers of subjects examined } \\
\text { 'Significant differences in proportions of dark and pale lymphocytes with positive reaction in all subjects } \\
\text { 'Significant difference in proportions of dark and pale lymphocytes in only one subject in these groups (dark }>\text { pale in PAS, pale }>\text { dark } i \\
\text { toluidine blue) } \\
\text { 'In two subjects tested, exposure to } L(+) \text { tartaric acid abolished the positive reaction in the three groups of cells. }\end{array}$} \\
\hline
\end{tabular}


It is uncertain if lymphocytes distinguished as 'basophil' and 'pale' in this investigation have counterparts in other nomenclatures. It seems likely, however, that pale lymphocytes are the same as the 'large' lymphocytes of Bessis (1973). It is uncertain, however, if the division we propose has relevance to the classification of lymphocytes into $T$ and $B$ types. In lymphatic malignancies there is correlation between cytochemistry and $\mathbf{T}$ or $\mathbf{B}$ cell properties (Catovsky et al., 1974; Brouet et al., 1975). Our findings in normals cannot readily be compared with these, though the cytology of the leukaemic cells in some of the patients of Brouet et al. with T cell chronic lymphocytic leukaemias could suggest a relation to 'pale' cells.

We wish to thank Dr D. Galton, London, Professor A. Pound, Brisbane, Professor A. Basten, Sydney, and Dr I. Green, Bethesda, USA, for their helpful advice; Mrs I. Forbes, Royal Brisbane Hospital, for skilled technical assistance; Mr B. Stewart, Royal Brisbane Hospital, for photomicrography; Mrs G. Williams, University of Queensland, for statistical analyses; and the Queensland Children's Research Foundation for a grant for the colour illustrations.

\section{References}

Bessis, M. (1973). Living Blood Cells and Their Ultrastructure, translated by R. I. Weed, p. 421. Springer, Berlin and New York.

Brouet, J-C. Flandrin. G., Sasportes, M., Preud'Homme, J-L., and Seligmann, M. (1975). Chronic lymphocytic leukaemia of T-cell origin. Lancet, 2, 890-893.

Catovsky, D., Galetto, J., Okos, A., Miliani, E., and Galton, D. A. G. (1974). Cytochemical profile of B and
T leukaemic lymphocytes with special reference to acute lymphoblastic leukaemia. J. clin. Path., 27, 767-771.

Dacie, J. V. and Lewis, S. M. (1968). Practical Haemato$\log y$, 4th edition. Churchill, London.

Goldberg, A. F. and Barka, T. (1962). Acid phosphatase activity in human blood cells. Nature (Lond.), 195, 297.

Good, R. A. (1972). Lymphocyte surface markers. New Engl. J. Med., 287, 305-6.

Good, R. A. (1973). Crucial experiments of nature that have guided analysis of the immunologic apparatus. In Immunologic Disorders in Infants and Children, edited by E. R. Stiehm and V. A. Fulginiti, pp. 3-15. Saunders, Philadelphia.

Hong, R. and Ammann, A. J. (1973). Lymphocytes and delayed hypersensitivity. In Immunologic Disorders in Infants and Children, edited by E. R. Stiehm and V. A. Fulginiti, pp. 67-84. Saunders, Philadelphia.

Kaplow, L. S. (1965). Simplified myeloperoxidase stain using benzidine dihydrochloride. Blood, 26, 215-219.

Lawton, A. R. and Cooper, M. D. (1973). Development of immunity: phylogeny and ontogeny. In Immunologic Disorders in Infants and Children, edited by E. R. Stiehm and V. A. Fulginiti, pp. 28-41. Saunders, Philadelphia.

Lorbacher, R. P., Yam, L. T., and Mitus, W. J. (1967). Cytochemical demonstration of $\beta$-glucuronidase activity in blood and bone marrow cells. J. Histochem. Cytochem., 15, 680687.

Muir, H., Mittwoch, U., and Bitter, T. (1963). The diagnostic value of isolated urinary mucopolysaccharides and of lymphocyte inclusions in gargoylism. Arch. Dis. Childh., 38, 358-363.

Stiehm, E. R. (1973). Immunodeficiency disorders: general considerations. In Immunologic Disorders in Infants and Children, edited by E. R. Stiehm and V. A. Fulginiti, pp. 145-167. Saunders, Philadelphia.

Yam, L. T., Li, C. Y., and Crosby, W. H. (1971). Cytochemical identification of monocytes and granulocytes. Amer. J. clin. Path., 55, 283-290. 